\title{
Study of Elderly Needs to Service of Santun Lansia Health Center
}

\author{
Kurniawan Yudianto, Fadiah Izzati Salim, Citra Windani Mambang Sari \\ Faculty of Nursing, Universitas Padjadjaran \\ Email : citra.windani@unpad.ac.id
}

\begin{abstract}
When a person become elderly people will slowly decline in physical function and psychological aspect affecting the economic and social conditions. The purpose of this study is to identify the needs of the elderly to Age-friendly Community Health Center (Puskesmas Santun Lansia) services in Puskesmas Puter. This research using quantitative descriptive method with 96 respondents who were taken by purposive sampling technique. The data collection technique using a questionnaire based on the concept of Agefriendly Community Health Center. Results were analyzed using univariate analysis with mean $/$ median. The result showed that $86.5 \%$ of elderly people requiring Age-friendly Community Health Centerservices and $47 \%$ of elderly people consider it important. All of respondent require servicing at dimensions promotive, preventive, rehabilitative, and ease of service. While the dimensions of curative required by all respondents. Most elderly people consider it important dimension of service on promotive, preventive, curative, rehabilitative, and ease of service. Based on research, it is expected the collaboration between the City Health Department and Community Health Center in the development of special program for elderly to improve quality of care for the elderly.
\end{abstract}

Keywords: Age-friendly community health center, elderly health care, needs assessment. 


\section{Introduction}

The success of a nation's development can be seen from the welfare of its population through increasing health status. One indicator of achievement of health degrees is the Age of Life Expectancy (UHH). In Indonesia, UHH increased from 69.09 in 2007 to 69.65 in 2012 (Ministry of Health $[\mathrm{MOH}], 2013)$. Demographically, the elderly population in Indonesia is among the top five in the world with the number of elderly in the 2010 population census amounting to 18.1 million people or $9.6 \%$ of the total population (MOH, 2013).

Along with the growth of the elderly population that continues to increase will cause various complex problems for the elderly themselves, their families, and the community. Elderly people will experience a decrease both physically and psychologically which affects their economic and social conditions (Mubarak, Santoso, Rozikin, \& Patonah, 2005). For this reason, the elderly problem needs to get serious attention from all sectors in an effort to improve the welfare of the elderly.

The size of the population and problems of the elderly have not been followed by the availability of adequate facilities and infrastructure, especially in the health sector. So there is a need for special health services for the elderly to support the condition of the elderly who have experienced changes both physiologically, psychologically, socially, and economically.

In Indonesia, the government has developed a health care policy for the elderly in basic health services through the Elderly Community Health Center program. Elderly Public Health Center is a health center that performs services to the elderly by prioritizing promotive and preventive aspects in addition to curative and rehabilitative aspects which emphasize more pro-active, polite towards the elderly, and provide facilities and support for the elderly. Facilities and services provided by elderly well-mannered Puskesmas are available for special counters, special service rooms and all facilities that make it easier for elderly people to get services (especially elderly waiting rooms, corridors with handles, stairs with handles and not too steep, toilets with handles etc.), and have workers who have been trained in the field of elderly health (MOH, 2010).

Puskesmas Puter is one of the puskesmas that implements the Elderly Community Health Center program and as a pilot health center in the city of Bandung. Facilities and infrastructure available at the Puskesmas Puter include special elderly counters, elderly waiting rooms, elderly poly examinations.

The visit of the elderly from year to year has increased, as seen from data from elderly visits to the Puskesmas Puter for the past three years. The average visit in 2012 was 680 per month, then in 2013 it became 754 elderly patients per month, and in 2014 it was 897 elderly patients per month. This condition is a challenge for Puskesmas to provide the best services according to the needs of the elderly by increasing special services for the elderly through the Elderly Community Health Center Program.

Based on the description above, the researchers were interested in conducting research on "Elderly Needs Assessment of Elderly Public Health Services in Puter Community Health Centers". Through this research, the services needed by elderly patients and those who have not been accommodated by the Puskesmas will be identified.

\section{Research Method}

This research was conducted at the Puter City Health Center in Bandung using quantitative descriptive methods. The variable in this study is the need for the elderly to service the Elderly Community Health Center. While the sub-variables of this study are the needs of the elderly towards promotive, preventive, curative, rehabilitative, and ease of service.

The population in this study was the number of elderly targets in the Puter Community Health Center area in 2015, namely 2142 elderly people. The sampling technique used is purposive sampling technique. Based on the formula from Taro Yamane or Slovin (Riduwan, 2012) with a level of significance (level of significance) $90 \%$, obtained a sample of 96 respondents. The inclusion criteria in this study were the 
elderly who had visited the Puskesmas at least once. While the exclusion criteria are the elderly who have limited communication and are not cooperative in the study.

The technique of collecting data uses a questionnaire that was made by the researcher based on the conceptual basis of the Elderly Community Health Center program. The questionnaire uses two parts of the answer, the first part is to assess the needs of the elderly for services using a Likert scale with a score of $1=$ necessary and $0=$ unnecessary. Then if the respondent answers the need, proceed to the second part, namely to measure the level of interest of the elderly towards service using a Likert scale with a range of $1-4$, with a score of $1=$ not important, 2 = normal, 3 = important, and $4=$ very important. The questionnaire used has gone through the validity test (content validity) so that there are 45 items of positive statements and reliability tests with the value of Cronbach Alpha coefficient 0.890 which means high instrument reliability.

\section{Research Results}

Table 1 Frequency Distribution of Elderly Needs Assessment of Elderly Public Health Services based on Respondent Characteristics at Puter Community Health Center $(n=96)$

\begin{tabular}{lcc}
\hline \multicolumn{1}{c}{ Characteristic } & Frequency & \% \\
\hline Age & 81 & 84 \\
$60-74$ & 15 & 16 \\
$75-87$ & & \\
Gender & 37 & 38.5 \\
Male & 59 & 61.5 \\
Female & & \\
Education & 3 & 3 \\
Never go school & 3 & 3 \\
Did not finish school & 36 & 38 \\
Elementary & 29 & 30 \\
Junior High & 13 & 14 \\
Senior High & 12 & 13 \\
Academy & & \\
Occupation & 23 & 24 \\
Pension & 3 & 3 \\
Private & 6 & 6 \\
Entrepreneur & 1 & 1 \\
Does not work & 56 & 58 \\
Housewife & 8 & 8 \\
Other & & \\
Status Marital & 47 & 49 \\
Married & 49 & 51 \\
Widow & & 28 \\
Monthly income & 27 & 72 \\
$>$ Rp 2.310.000 & 69 & \\
$<$ Rp 2.310.000 & & \\
\hline & & \\
\hline
\end{tabular}


Kurniawan Yudianto: Study of Elderly Needs to Service of Santun Lansia Health Center

\begin{tabular}{lcc}
\hline \multicolumn{1}{c}{ Characteristic } & Frequency & \% \\
\hline Ethnic & 71 & 74 \\
Sundanes & 16 & 17 \\
Javanese & 9 & 9 \\
Other & & \\
Religion & 90 & 94 \\
Moslem & 4 & 4 \\
Catholic & 2 & 2 \\
Protestan & & \\
Live with & 8 & 8 \\
Alone & 36 & 38 \\
Spouse & 38 & 40 \\
Daughter & 11 & 11 \\
Spouse and Children & 3 & 3 \\
Other & & \\
Visit to Health Care Center in 1 & 46 & 48 \\
month & 15 & 16 \\
1 times & 27 & 28 \\
2 times & 8 & 8 \\
3 times & & \\
4 times & & \\
\hline
\end{tabular}

Table 2 Elderly Needs Assessment of Elderly Public Health Center Services in Puskesmas and Elderly Needs for Promotive, Preventive, Curative and Rehabilitative Services and Ease of Service

\begin{tabular}{lcccc}
\hline \multirow{2}{*}{ Variables and Subvariables } & \multicolumn{2}{c}{ Need } & \multicolumn{2}{c}{ No need } \\
\cline { 2 - 5 } & f & \% & f & \% \\
\hline Elderly Needs for Elderly Community Health Center & 83 & 86.5 & 13 & 13.5 \\
Services & & & & \\
Elderly Needs for Promotive Services & 87 & 91 & 9 & 9 \\
Elderly Needs for Preventive Services & 88 & 92 & 8 & 8 \\
Elderly Needs for Curative Services & 96 & 100 & 0 & 0 \\
Elderly Needs for Rehabilitative Services & 85 & 88.54 & 11 & 11.46 \\
Elderly Needs for Ease of Service & 93 & 96.88 & 3 & 3.13 \\
\hline
\end{tabular}

Table 1 Frequency Distribution of Elderly Needs Assessment of Elderly Public Health Services based on Respondent Characteristics at Puter Community Health Center $(\mathrm{n}=96)$

Based on Table 1 shows that the age of the respondents is in the age range of $60-87$ years with $61.5 \%$ female sex while men as much as $38.5 \%$. The highest level of education of the last respondent was at the elementary level of $38 \%$. The highest occupation of respondents is IRT at $58 \%$. The marital status of married respondents and $72 \%$ have monthly income $<$ UMK. The majority of the tribes were $74 \%$ of Sundanese people. The religion held by the respondents was mostly Muslim by $94 \%$. Respondents who live with children as much 
Kurniawan Yudianto: Study of Elderly Needs to Service of Santun Lansia Health Center

Table 3 Elderly Needs Assessment of Elderly Public Health Center Services in Puskesmas and Elderly Needs for Promotive, Preventive, Curative and Rehabilitative Services and Ease of Service

\begin{tabular}{lcccccccc}
\hline \multirow{2}{*}{ Subvariabel } & \multicolumn{2}{c}{ Not Important } & Normal & Important & \multicolumn{2}{c}{$\begin{array}{c}\text { Very } \\
\text { Important }\end{array}$} \\
\cline { 2 - 9 } & \multicolumn{1}{c}{ f } & $\mathbf{\%}$ & $\mathbf{f}$ & $\mathbf{\%}$ & $\mathbf{f}$ & $\mathbf{\%}$ & $\mathbf{f}$ & $\mathbf{\%}$ \\
\hline Elderly Needs for Elderly Community & 1 & 1.2 & 13 & 15.7 & 61 & 73.5 & 8 & 9.6 \\
Health Center Services & & & & & & & & \\
Elderly Needs for Promotive Services & 3 & 3.4 & 23 & 26.4 & 50 & 57.5 & 11 & 12.6 \\
Elderly Needs for Preventive Services & 0 & 0 & 0 & 0 & 61 & 73.5 & 8 & 9.6 \\
Elderly Needs for Curative Services & 0 & 0 & 1 & 1.0 & 66 & 68.8 & 29 & 30.2 \\
Elderly Needs for Rehabilitative & 8 & 9.4 & 20 & 23.5 & 54 & 63.5 & 3 & 3.5 \\
Services & & & & & & & & \\
Elderly Needs for Ease of Service & 1 & 1.1 & 31 & 33.3 & 51 & 54.8 & 10 & 10.8 \\
\hline
\end{tabular}

as $40 \%$ and who live with a partner $38 \%$. Respondents who visited the Puskesmas were at least 1 time a month as much as $48 \%$.

From table 2 illustrates that of the 96 respondents studied, respondents who felt they needed the services of Elderly Community Health Center were 83 people $(86.5 \%)$ while those who felt they did not need the services of Elderly Public Health Center were 13 people $(13.5 \%)$. Respondents who felt they needed the services of the Puskesmas Santun Lansia subvariabel promotive services were 87 people $(91 \%)$, while those who felt they did not need promotive services were 9 people $(9 \%)$. Subvariables of preventive services were 88 people $(92 \%)$ while those who felt they did not need preventive services were 8 people $(8 \%)$. Respondents who felt they needed the services of the Elderly Community Health Center were subvariable with 96 curative services $(100 \%)$. Rehabilitation was 85 people $(88.54 \%)$ while those who felt they did not need rehabilitative services were 11 people (11.64\%). Subvariable elderly with ease of service as many as 93 people (96.88\%) while those who felt did not need the ease of service as many as 3 people $(3.13 \%)$.

From table 3 illustrates that of the respondents who felt they needed the services of Elderly Public Health Center, as many as 1 person $(1.2 \%)$ felt that Elderly Community Health Center services were not important, 13 people (15.7\%) said it was normal, 61 people $(73.5 \%)$ felt important, and 8 people $(9.6 \%)$ considered the services of the Elderly Community Health Center to be very important. The needs of the elderly for promotive services, namely as many as 3 people $(3.4 \%)$ felt that service was not important, 23 people $(26.4 \%)$ said it was normal, 50 people $(57.5 \%)$ felt it was important, and 11 people $(9.6 \%)$ considered it very important. The needs of the elderly for preventive services, namely as many as 1 person $(1.2 \%)$ felt service was not important, 13 people $(15.7 \%)$ said normal, 61 people $(73.5 \%)$ felt it was important, and 8 people $(9.6 \%)$ considered it very important. The needs of the elderly for curative services, namely as many as 1 person $(1 \%)$ felt ordinary service, 66 people $(68.8 \%)$ felt important, and 29 people (30.2\%) considered it very important. The needs of the elderly for rehabilitative services, which are as many as 8 people $(9.4 \%)$ feel that service is not important, 20 people $(23.5 \%)$ say normal, 54 people $(63.5 \%)$ feel important, and 3 people $(3.5 \%)$ consider it very important. The needs of the elderly for ease of service, namely as many as 1 person $(1.1 \%)$ felt that service was not important, 31 people $(33.3 \%)$ said it was normal, 51 people $(54.8 \%)$ felt it was important, and 10 people (10.8\%) considered it very important.

\section{Discussion}

The need for health services increases with age. A comprehensive health service approach for the elderly is expected to be able to respond to the aspirations of the elderly and 
understand the capacity of the elderly based on changes experienced through effective, safe, efficient and responsive services, without burdening individual costs (Beard \& Bloom, 2014; Suzman et al., 2014).

The results showed that in general the elderly were 83 people $(86.5 \%)$ who felt the need and needed the services of the Elderly Community Health Center. Of the 83 elderly who needed the Elderly Public Health Center service, the majority were $61 \%$ considered important, $13 \%$ ordinary, $8 \%$ said it was very important, and 15 did not consider it important to the services of the Elderly Community Health Center. This is supported by a survey conducted by Suriastini et al. (2013) regarding an elderly friendly city assessment study in the city of Bandung. It was concluded that health services and community support for the promotion and maintenance and recovery of elderly health were quite good with $63.3 \%$ achievement. For this reason, support from the government from the health aspect is expected to meet the expectations of the elderly for friendly, courteous, and supportive services for the elderly's physical condition.

One of the main principles that must be fulfilled in health services for the elderly is holistic service, which must include aspects of promoting promotion, prevention (healing), healing (curative), and recovery (rehabilitative). Health centers as basic health services must implement simple, promotional, preventative, curative and rehabilitation efforts. Besides that, Elderly Community Health Center services must provide good, quality and polite service, provide facilities for the elderly, and provide relief for health care costs especially for financially disadvantaged elderly people (MOH, 2010).

Based on the results of the study, 87 of the 96 respondents felt the need for promotive service and most of the elderly $(57.5 \%)$ considered it important to the needs of promotive services. This means that these services are needed and considered urgent to be provided by the puskesmas.

Promotive services that have the highest percentage are aspects of nutrition for the elderly, where most of the elderly $(63.2 \%)$ consider it important. So the puskesmas need to provide services that support the promotive aspects through counseling, consultation and checking the nutritional status of the elderly. Given the limitations of the elderly, it is important for puskesmas to carry out counseling using media that is easily understood by the elderly both in audio and visual forms. In addition, the puskesmas can provide reading resources about health information especially for the elderly.

Based on the results of the study, 88 out of 96 respondents felt the need for preventive services and in general the elderly $(73.5 \%)$ considered the importance of preventive service needs. Preventive services can take the form of regular and regular health checks to find out early age diseases (Asfriyati, 2003).

The aspects of preventive services that have the highest percentage are generally (76.1\%) elderly consider important aspects of early detection such as anthropometric examination (TB and $\mathrm{BB}$ ), blood pressure checks, laboratory tests regarding complete blood checks, cholesterol, blood sugar, acid veins, and other investigations. In line with the research conducted by Fadzillah (2013), the majority of the pre-elderly who received services at the elderly posyandu needed a simple laboratory examination.

For curative services, all respondents $(96$ elderly) needed service and most (68.8\%) considered it important. And the highest percentage is that most of the elderly consider treatment as important $(69.8 \%)$ and referral services $(67.7 \%)$. This is supported by research conducted by Kadar, McKenna, and Francis (2014), concluding that $77.8 \%$ of health workers performed curative services in the form of medication compared to health education, which was $61.1 \%$ lower. This proves that the elderly who are synonymous with various health problems such as degenerative diseases desperately need treatment as the main prevention of the occurrence of disease complications.

The needs of the elderly for rehabilitative services, as many as 85 out of 96 respondents felt the need for services and most $(63.5 \%)$ considered it important. The category that gets the highest percentage is in the important category where in all aspects most of the elderly consider it important 
Kurniawan Yudianto: Study of Elderly Needs to Service of Santun Lansia Health Center

both psychosocial efforts $(58.8 \%)$, medical efforts $(54.1 \%)$, and educative $(51.8 \%)$. Rehabilitative efforts carried out are medical, psychosocial, educative, among others, providing information, knowledge and services about the use of various tools, restore self-confidence and strengthen the mentality of sufferers, advice on how to live in accordance with the illness suffered, and physiotherapy treatment.

The ease of service is needed by 93 respondents from 96 and most (54.8\%) consider it important. All aspects are included in the highest important category, where most consider the facilities and infrastructure important $(52.7 \%)$ and low costs $(50.5 \%)$. The age of elderly respondents in the range 60-87 shows that the older the elderly, the more demanding the availability of facilities that help their needs. Characteristics of research respondents who mostly have less monthly income than UMK both from income and gifts from family or relatives. While the aspect of health workers is considered important in almost half $(49.5 \%)$ The last education of the elderly who are almost half in the elementary school level shows that puskesmas officers are needed who are able to communicate in a language that is easily understood by elderly patients with low education. Quality is perceived well, if officers have attention, respect, sensitivity and have the ability quickly and precisely in responding to complaints and providing information according to the needs of patients (Ambariani et al., 2014).

\section{Conclusion}

Based on the results of the study of 96 respondents in the Puskesmas Puter and after analysis and discussion, it can be concluded that the elderly in general, $86.5 \%$ need the Elderly Public Health Center service and the highest percentage considers the services of the Elderly Public Health Center to be large $(73.5 \%)$ elderly.

\section{References}

Asfriyati. (2003). Upaya pembinaan dan pelayanan kesehatan usia lanjut. USU Digital Library.

Beard, J.R., \& Bloom, D.E. (2014). Towards a comprehensive public health response to population ageing. The Lancet, 658 .

Depkes RI: Direktorat Jendral Bina Upaya Kesehatan Kementerian Kesehatan RI. (2013). Sehat di masa lanjut usia. Retrieved from http://buk.depkes.go.id/index. php?option $=$ com_content $\&$ view $=$ article $\&$ id =393: sehat-di-masa-lanjut-usia\&catid=111:d asar\&Itemid $=136$.

Depkes RI. (2010). Pedoman puskesmas santun lanjut usia bagi petugas kesehatan. Jakarta: Departemen Kesehatan RI.

Fadzillah, U. (2013). Persepsi dan kebutuhan pra lanjut usia (pra lansia) tentang posyandu lansia di Kelurahan Mayangan Kecamatan Wiradesa Kabupaten Pekalongan.

Kadar, K., McKenna, L., \& Francis, K. (2014). Scoping the context of programs and services for maintaining wellness of older people in Rural Areas of Indonesia. International Council of Nurses, 1.

Kemenkes RI. (2013). Buletin jendela data dan informasi kesehatan: Gambaran kesehatan lanjut usia di Indonesia. Jakarta: Pusat Data dan Informasi Kemenkes RI.

Mubarak, W.I., Santoso, A.B., Rozikin, K., \& Patonah, S. (2005). Ilmu keperawatan komunitas 2. Jakarta: Sagung Seto.

Suriastini, N.W., Bondan, S.S., Rahardjo, T.B., Mulyanto, E.D., Fauzan, J., Naryanta, et al. (2013). Satu langkah menuju impian lanjut usia kota ramah lanjut usia 2030: Kota Bandung. Yogyakarta: SurveyMETER. 